\title{
11 Advancing the rights of sexual and gender minorities under the African Charter on Human and Peoples' Rights
}

\author{
The journey to Resolution 275
}

\author{
Berry D. Nibogora
}

\section{Introduction}

The advocacy paths around protection of individuals from violence and other violations of human and peoples' rights based on sexual orientation, gender identity and expression and sex characteristics have been a struggle. Two steps forward, one step backward. This is true for a number of areas in which the rights discourse faces more controversies on the African continent (abortion, women's rights, child rights, etc.), be it due to lack of written documentation or the state of denial that exists in a number of countries. ${ }^{1}$

This chapter is divided in five sections. After the introduction, the second section discusses the application of international human rights law to sexual and gender minorities ${ }^{2}$ in Africa with a focus on the role of the Commission. The third section explores strategies implemented to achieve the adoption of the resolution on protection against violence and other human rights violations based on real or imputed sexual orientation and gender identity (Resolution 275). Section four deep-dives into the context around the passing of and the reactions to Resolution 275 . The fifth and last section concludes with the way forward in the struggle for equality in Africa.

This introduction looks at the challenges faced by sexual and gender minorities in Africa. Firstly, 33 countries explicitly criminalize same-sex sexuality and gender non-conforming identity generically referred to as homosexuality. ${ }^{3}$ Documented evidence has shown that criminalization of same-sex sexual conduct forces homosexual persons of all ages to live in absolute fear of harassment, torture, extortion, mob violence and denunciation. ${ }^{4}$ Arguably, criminalization deprives people of their dignity and most basic rights, rendering them utterly vulnerable and, in some cases, effectively disenfranchized. ${ }^{5}$ Using Kenyan context as a case study, Shaw describes criminalization as a dignity taking, directly through forced anal examinations, and indirectly through state-sanctioned violence. ${ }^{6}$

Secondly, even in countries where there is no anti-homosexuality laws or where protective laws do exist such as South Africa, public sentiments led by religious ${ }^{7}$ conservatism and homophobia create a social environment that 
actively oppresses LGBTIQA individuals within their families, at school, at workplace and in the broad community. ${ }^{8}$ In most African countries where there is no specific law criminalizing homosexuality, there is generally an unspoken rule of tolerance called by Kerrigan the 'don't ask, don't tell' code: as long as LGBTIQA are silent and discreet about who they are and what issues they face, they will be tolerated. ${ }^{9}$ Rudman sees it not as tolerance of one's sexual life but as deliberate ignorance of a hidden behaviour. ${ }^{10}$ The knowledge by family members, neighbours, school teachers, employers and the broad community of one's homosexuality leads to far-reaching consequences ranging from being disowned, bullied, physically and verbally abused, stigmatized and discriminated against, etc. ${ }^{11}$

Thirdly, violations of human rights of LGBTIQA persons in many African countries seem to be justified by the criminal label associated with their identity. The general public, under religious and homophobic influence, sees violation of LGBTIQA rights not as illegal but rather as 'a crime of honour' that enjoys flagrant impunity. ${ }^{12}$ This makes access to justice inefficient in most African countries for LGBTIQA victims of ordinary crimes as perpetrators' tactics to raise their (homo)sexuality turn them into targets of prosecutions in instances where they appeared first as victims. ${ }^{13}$

Fourthly, the challenges faced by sexual and gender minorities are heightened by a systematic social exclusion from development programmes, be it within the 2030 United Nations sustainable development agenda or the African Union Agenda 2063. Poku et al. describe the continental experience of LGBTI exclusion from markets, including housing, employment, economic opportunity, participation in family or community credits schemes, religious and cultural spaces, etc. ${ }^{14}$ They conclude that although it is strategic and opportune to push for social inclusion of sexual and gender minorities in the development progammes as unconditional requirement for 'leaving no one behind', 'data are still needed to understand the ways in which sexuality and gender interact with other facets of identity to create multiple and interlocking forms of exclusion' of LGBTIQA people across Africa. ${ }^{15}$

Given the protection gaps of LGBTIQA rights at national and sub-national levels, regional and international human rights bodies have repeatedly stressed the importance of state compliance with the obligation to respect, protect and fulfil human rights for LGBTIQA persons, recalling that human rights principles are applicable to sexual and gender minorities. ${ }^{16}$ In the next section, we focus on the particular role of the Commission.

\section{Application of human rights law to sexual and gender minorities in Africa and the role of the Commission}

\subsection{International human rights law and the protection of sexual and gender minorities}

Despite different biases that drive the opposition to the applicability of human rights to sexual and gender minorities in Africa, ${ }^{17}$ the legal obligations of states to safeguard human rights of sexual and gender minorities are well established 
under international human rights law, be it within the framework of the Universal Declaration of Human Rights or subsequent human rights instruments ratified by member states. The jurisprudence of human rights bodies has been unequivocal: all people irrespective of sex, sexual orientation or gender identity, are entitled the protection provided for by international human rights law, including the rights to life, security of person and privacy, non-discrimination, association, peaceful assembly and freedoms from torture, arbitrary arrest and detention, of expression, etc. ${ }^{18}$

The United Nations (UN) treaty bodies asserted states obligations in relation to human rights of sexual and gender minorities on numerous occasions. As early as 1994, in the case of Toonen v Australia (Toonen case), the UN Human Rights Committee held that the criminalization of same-sex conduct between consenting adults breaches the state obligation to protect individual privacy and to guarantee non-discrimination.

In the case of $X v$ Colombia, the same Committee held that the prohibition against discrimination under Article 26 of the International Covenant on Civil and Political Rights (ICCPR) comprises also discrimination based on sexual orientation.

In the same vein, the UN Committee on Economic, Social and Cultural rights (Committee on ESCR) stated in General Comment No 20 that

states parties should ensure that a person's sexual orientation is not a barrier to realising Covenant rights, for example, in accessing survivor's pension rights. in addition, gender identity is recognised as among prohibited grounds of discrimination; ... .

Similarly, the Committee on the Elimination of all forms of Discrimination against Women (the CEDAW Committee) stressed that 'discrimination against women based on sex and gender is inextricably linked with other factors that affect women, such as ... sexual orientation and gender identity'.

Further, the Committee against Torture and other Cruel, Inhuman and Degrading Treatment or Punishment (Committee against Torture) held that

states parties must ensure that, in so far as the obligations arising under the Convention are concerned, their laws are in practice applied to all persons, regardless of ... sexual orientation (or) transgender identity.

Other regional human rights mechanisms have made similar explicit pronouncements. The European Court on human rights has moved from the negative-obligation approach to sexual orientation and gender identity based on the right to privacy to a more positive approach by striking down antisodomy laws using anti-discrimination provision and further cementing the entitlement to equality regardless of one's sexual orientation or gender identity. ${ }^{19}$ Similarly, the Inter-American human rights monitoring bodies repeatedly made it clear that the scope of non-discrimination clauses undoubtedly 
include sexual orientation and gender identity. In the landmark case of Karen Atala and Daughters $v$ Chile (Atala Case) the Court concluded:

Bearing in mind the general obligations to respect and guarantee the rights established in article 1(1) of the American Convention, ...the sexual orientation of persons is a category protected by the Convention. Therefore, any regulation, act or practice considered discriminatory based on a person's sexual orientation is prohibited. Consequently, no domestic regulation, decision, or practice, whereby states authorities or individuals may diminish or restrict, in anyway whatsoever, the rights of a person based on his or her sexual orientation.

It is argued that the above jurisprudence applies within the African context given that the Commission, in interpreting the provisions of the African Charter draws inspiration from international law and takes into consideration other general or special conventions in determining the principles of law.

Although some scholars considered that the questions of sexual orientation and gender identity have remained on the margins of international human rights law and outside the consideration of the Commission, ${ }^{20}$ this is no longer the case given that international human rights bodies' jurisprudence and the Commission's practice have unequivocally asserted sexual orientation and gender identity as protected grounds from discrimination. ${ }^{21}$

\subsection{The role of the Commission in advancing LGBTIQA rights in Africa}

The Commission played a key role in advancing human and peoples' rights of sexual and gender minorities in Africa. Over the years, it indirectly recognized that the African Charter prohibits violence and discrimination on the basis of sexual orientation and gender identity. This submission is based on the following arguments.

Firstly in 2006, in the case of Zimbabwe Human Rights NGO Forum $v$ Zimbabwe, the Commission stated that Article 2 of the African Charter provides for 'equality of treatment for all individuals irrespective of ... sexual orientation'.

Secondly, in its first general comment adopted in 2012 on Article 14 (1) (d) and (e) of the Protocol to the African Charter on the Rights of Women in Africa, the Commission stated that:

3. Given the susceptibility of women to HIV and related rights abuses in Africa, the African Commission recognises that the societal context based on gender inequalities, power imbalances and male dominance has to be addressed and transformed in order for women to meaningfully claim and enjoy freedom from violence....

4. According to the African Commission, there are multiple forms of discrimination based on various grounds such as: race, sex, sexuality, sexual orientation... 
Read together, these two paragraphs suggest that the Commission acknowledged that, on one hand, the root causes of gender inequalities affecting women reside in the power imbalance and male dominance. On the other hand, for women to meaningfully enjoy the rights in the Protocol and be free from violence, discrimination based on race, sex, sexuality and sexual orientation, age, disability, harmful customary practice and religion must be addressed. Garrido argues that the Commission's inclusion of sexual orientation as a prohibited ground of discrimination as well as LGBTI amongst the vulnerable and disadvantaged groups in the 2011 Guidelines and Principles on Economic, Social and Cultural rights was the most relevant recognition of the African human rights systems. ${ }^{22}$

Equally, in its General Comment No 4 on the right to redress for victims of torture and other cruel, inhuman and degrading punishment or treatment under Article 5 of the African Charter, the Commission acknowledged that:

...Acts of sexual violence against men, boys, persons with psychological disabilities, and lesbian, gay, bisexual, transgender and intersex persons are of equal concern and must also be adequately and effectively addressed by State parties.

Thirdly, the Commission has raised concerns over violence and discrimination targeting sexual and gender minorities in countries under review not only during the interactive dialogue between commissioners and state delegates but also and most importantly in the concluding observations and recommendations to states.

Fourthly, the Commission issued in 2014 the resolution on protection against human rights violations against persons on the basis of sexual orientation or gender identity. Resolution 275 urges member states to end all acts of violence committed by states or non-state actors by:

...enacting and effectively applying appropriate laws prohibiting and punishing all forms of violence including those targeting persons on the basis of their imputed or real sexual orientation or gender identities, ensuring proper investigation and diligent prosecution of perpetrators, and establishing judicial procedures responsive to the needs of victims.

This resolution was adopted within the mandate of the Commission, which is two-fold: promotion and protection of human and peoples' rights enshrined in the African Charter. The protective mandate of the Commission is contained in Article 45(2) and detailed in Articles 47 to 55, whereas the promotional mandate is in Article 45(1) of the African Charter. An interpretation of Article 45(1) allowed the Commission, in its efforts to 'formulate and lay down principles and rules aimed at solving legal problems relating to human and peoples' rights', to adopt resolutions to address various human rights issues. Resolutions issued by the Commission can be classified in three types: 
(1) thematic resolution, (2) administrative resolutions and (3) country-specific resolutions.

Thematic resolutions elaborate in greater details the states' obligations in respect of a specific right and describe the standard set by the Charter. Administrative resolutions deal with the Commission's procedures, internal mechanisms and relationship between the Commission and other stakeholders. Country resolutions address pertinent human rights concerns in member states.

As the centre-piece of this chapter, Resolution 275 is a thematic resolution articulating states' obligation to end violence and other human rights violations against persons on the basis of their real or imputed sexual orientation or gender identity.

Part of the challenges related to the protection of LGBTIQA rights is that the binding nature of the Commission's resolutions has been questioned by states and enforcement has been elusive over the years. ${ }^{23}$ Further, the Commission has been divided on the issue of sexual orientation as some commissioners do not see it as a human right issue, but rather a matter that hits their moral and religious stand. ${ }^{24}$ The adoption of Resolution 275 was a culmination of strategic and tireless efforts.

\section{The road to Resolution 275: strategic choices and key moments}

Struggles for human rights to equality and non-discrimination of African LGBTIQA must be understood as part of the liberation process. Liberation of our minds, of our bodies, and of our sexuality from a third-party control or simply from oppression. As argued by Heyns, "human rights are not dependant on recognition by the state. People can claim them even when the law, whether made by a dictator or by the majority, denies those rights'. ${ }^{25}$ Moreover, the denial against LGBTIQA rights is deeply influenced by religion and morality, which perpetuate patriarchal and capitalistic gender inequalities, as one of the feminist scholars explains: ${ }^{26}$

As one of the most important forces that influence the belief systems that African people have, shaping and defining the deepest values that they hold, religion heavily impact on issues of sexual morality. The sexual morality espoused by most religions and the law perpetuates gender hierarchies, thereby depriving certain groups of their full citizenship.

Given the hostility of national contexts, activists turned to supra-national human rights bodies - such as the Commission - to achieve equality and no discrimination in respective African countries. Indeed, despite their legal limitations 'there is no doubt that [resolutions passed by the Commission] remain important soft law to hold government accountable to their obligations under the African Charter and other international human rights instruments'. ${ }^{27}$ 
For the purpose of this section, I will focus on the advocacy process that was deliberately followed to get Resolution 275 adopted. It can be summarized by the following cycle:

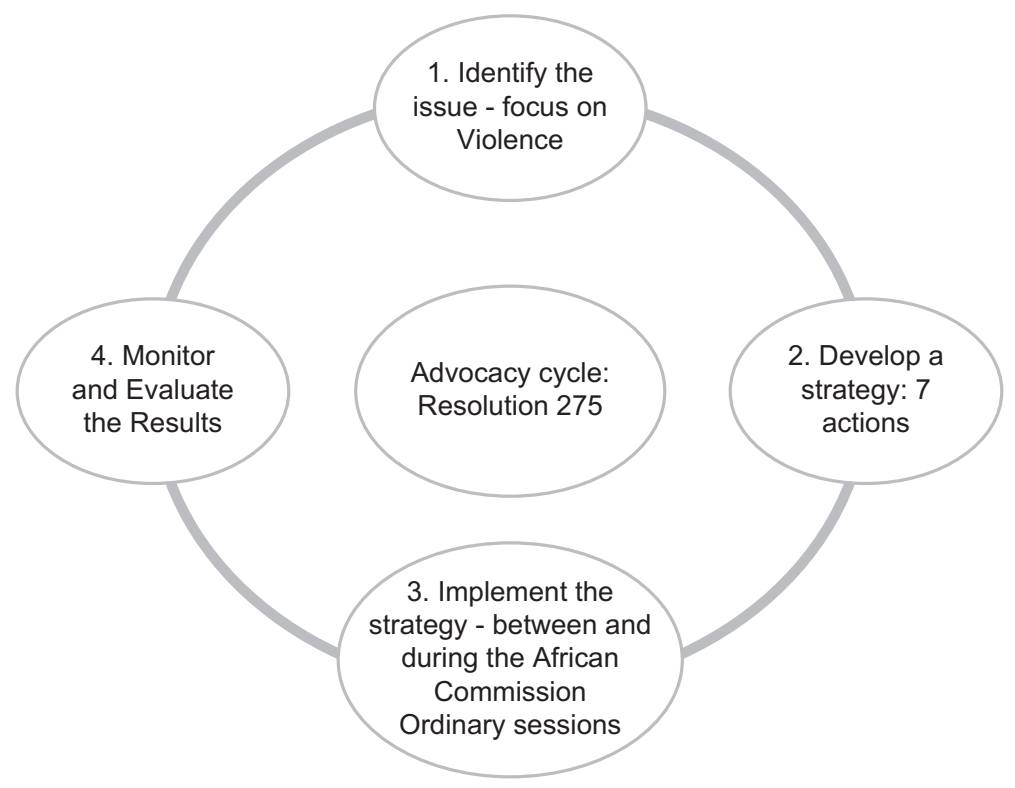

Figure 11.1 Making a strategic choice: why a resolution on violence?

The first step of the advocacy cycle for Resolution 275 was to identify the issue; which for the purpose of this journey was rather a choice of what to push for between a complaint before the Commission to obtain jurisprudence; a general comment; or a resolution to achieve recognition that sexual and gender minorities in Africa are indeed protected within the existing African human rights framework. ${ }^{28}$

The choice of a resolution was a logical conclusion for a number of reasons. First, the development of a general comment was not in the practice of the Commission before 2012. Second, exploring the litigation avenue has been an option that activists and researchers consistently cautioned about given the uncertainty of the outcome and the risk of a negative precedent that will take years to reverse. ${ }^{29}$

The choice of a resolution was, therefore, strategic given the likelihood of success, the relatively easy process to table it and get it adopted by the Commission. More strategic was the focus on violence and the reasons why it took precedence over other issues. Firstly, violence faced by LGBTIQA people in Africa was well-documented through shadow reports and newspaper articles. Secondly, violence is unanimously rejected and the least controversial theme even to those most homophobic. Lastly, by targeting not only 
those who self-identify as member of the LGBTIQA community but also their human rights defenders or family members, violence leaves none outside the protection gap, hence taking action was overdue.

\subsection{Developing and implementing an advocacy strategy: taking stock of decisive moments}

The second step was to develop a strategy, which consists of 'a plan of actions designed to achieve a long-term or overall aim' . ${ }^{30}$ The plan consisted of a series of coordinated actions, processes or messages 'intended to persuade or produce a particular corrective action' ${ }^{31}$ in this case the adoption of a resolution.

Below are a series of key processes undertaken between 2011 and the adoption of Resolution 275 in May 2014. The 1st action consisted of building a critical mass for each Commission's session to ensure visibility and disruption. The investment in physical participation and visibility of LGBTIQA people in all sessions shifted the mind of the general public and the Commission. The 2nd action was to document human rights violations based on SOGIESC. Civil society organizations such as the African Men for Sexual Health and Rights (AMSHeR) have been involved in documenting not only violations faced by the LGBTIQA persons but also positive contributions they bring to the society. ${ }^{32}$ Documentaries, web-series, short films emerged as powerful tools to mobilize solidarity from the general population.

In accordance with Rule 79(3) of the Commission,

Institutions, organizations or any interested party wishing to contribute to the examination of the Report and the human rights situation in the country concerned, shall send their contributions, including shadow reports, to the Secretary at least 60 days prior to the examination of the Report.

Activists working on Resolution 275 invested in shadow reporting to ensure evidence is brought to the attention of commissioners and state delegates during the review. This was successful in a number of cases, despite that submission of shadow reports as a strategy may not be all times efficient. ${ }^{33}$

The 3rd action consisted of alliances with mainstream civil society organizations. Countering hegemonic sexual discourses and addressing the protection gaps faced by sexual and gender minorities in Africa requires intersectionality $^{34}$ and building alliances among organizations through the NGO Forum ${ }^{35}$ or other meaningful ways. In 2012, LGBTIQA rights activists introduced the practice of side-events during the NGO Forum for civil society organizations to deep-dive into issues of specific interest to their work. This practice allowed SOGIESC activists to build alliances whilst evolving as credible partners within the civil society spectrum at the Commission.

The 4th action was to map key stakeholders using what was referred to as the 'traffic-light-exercise'. This exercise targeted the eleven commissioners who adopt resolutions either by consensus or by simple majority vote. The 
'traffic-light exercise' consisted of colouring commissioners in green - for allies who would vote in favour of a resolution condemning violence, in orange - for commissioners whose stand was not known either for not having engaged with them or for being new in the space, and red - for non-allies. The purpose of this session was to further devise strategies for engaging those in green to remain green, and those in orange and red to become green. ${ }^{36}$ One of such engagements consisted of side meetings with commissioners during ordinary sessions.

The above actions not only required coordination but also built on key opportunities that created momentum or milestones that marked the pathway towards the adoption of Resolution 275.

The first key moment is the decision to engage the Commission on LGBTIQA issues. In May 2006, the International Gay and Lesbian Human Rights Commission ('IGLHRC') in conjunction with CAL, Behind the Mask ('BTM') and All Africa Rights Initiative ('AARI') conducted an exploratory mission to Banjul, The Gambia. The mission was meant to study the space and establish challenges and opportunities to engage the Commission. However, when activists learnt that Cameroon was up for review, a small group was formed to draft accounts of violations based on SOGIESC, and submitted to the Commission an alternative statement to the state report. The statement informed the Commission's concluding observations raising concerns around an 'upsurge of intolerance against sexual minorities'.

The momentum was also gained through the growing role of the NGO Forum in adopting 'resolutions' subsequently submitted to the Commission for consideration. At the beginning, there was resistance from conservative NGOs. But due to the resiliency of activists, the Forum adopted its first-ever resolution with reference to SOGI ahead of the 41st session in 2007 and in subsequent sessions. However, the Commission did not endorse those resolutions and removed the words 'lesbians and bisexual' women. ${ }^{37}$

The second key moment is the denial of observer status to the Coalition of African Lesbians (CAL) and the wave of solidarity that followed from civil society organizations. The application was submitted by CAL in May 2008, the Commission took the decision to deny observer status to CAL on 20 October 2010. The reasons for denial were made public later stating that 'the activities of the said organization do not promote and protect any of the rights enshrined in the African Charter' ${ }^{38}$ An outcry of civil society solidarity marked the following session in November 2010, as most observers included in their statements a paragraph condemning the Commission's decision. ${ }^{39}$

The third key moment is the adoption of resolution 17/19 on human rights, sexual orientation and gender identity by the United Nations' Human Rights Council on 14 July 2011. The resolution mandated the office of high commissioner to conduct a study

documenting discriminatory laws and practices and acts of violence against individuals based on their sexual orientation and gender identity, in all regions of the world, and how international human rights law can be used 
to end violence and related human rights violations based on sexual orientation and gender identity.

Subsequent to this resolution, a series of regional meetings were held in various regions of the world but no such meeting was held in Africa. ${ }^{40}$ The process culminated in an international conference held in Oslo, Norway from 15 to 16 April 2013 and the co-chair meeting notes recognized an 'increased attention paid to the issues (of SOGIESC) by the African Commission ...'

The fourth decisive moment was the launch of the report on violence based on sexual orientation and gender identity in Africa, jointly authored by AMSHeR and CAL, documenting instances of violence across Africa. ${ }^{42} \mathrm{~A}$ commissioner was attending the NGO Forum and participated in the launch of the report. ${ }^{43} \mathrm{~A}$ draft resolution was adopted by the Forum condemning the instances of violence documented in the report. The same draft resolution was submitted to the Commission for consideration during the private session. It was not considered due to time constraints, ${ }^{44}$ but postponed for consideration at the following 55 th ordinary session.

\section{The passing of Resolution 275: context, content and usefulness}

The 55th session was held in Luanda, Angola from 28 April to 12 May 2014. As usual, activists held side events and engaged various stakeholders around SOGI issues, with the majority leaving after one week into the session. ${ }^{45}$

Circumstances played on the activists' side though. The session's schedule was light and postponed resolutions from the 54th session were tabled for consideration. Further, the Chairperson of the Commission Kayitesi Z. Sylvie, whose stand is well-known to be strongly opposed to SOGI issues, had to leave just after the opening of the private session due to personal reasons, leaving the co-chair role to Commissioner Alapini Gansou. Gansou's leadership and out-spoken support for equality and non-discrimination should not be underestimated given the powers of the Chair and Vice-chair of the Commission in terms of order of precedence, directing the conduct of business, moving motions, and closing discussion on matters before the Commission as a collective deliberating body. This factor played in favour of the adoption of Resolution 275.

Following the news of the adoption of Resolution 275, a wave of celebration followed, and messages flowed from the four corners of the globe commending the Commission. ${ }^{46}$ Sexual rights activists issued supportive statements to the extent that the International Human Rights Day, 10 December 2014, celebrated the passing of Resolution 275.

Adopting resolution 275 was an unprecedented move by the Commission. It sent a strong message that LGBTIQA people, like any other African, are fully entitled to protection provided by the African Charter against discrimination and violence. 
The content of Resolution 275 is three-fold. The first part gives the legal basis that the Commission used as a legitimate foundation of its action. This is Article 2 prohibiting distinction of any kind in the enjoyment of rights enshrined in the Charter by every individual; Article 3 prescribing equality and equal protection of the law; and Articles 4 and 5 read together, which in essence make life, dignity and integrity of the person sacred, including prohibition of torture and other forms of exploitation or cruel and inhumane treatment.

The second part sends an alarming warning due to instances of violence based on persons' real or perceived sexual orientation or gender identity. It lists different forms of violence, classifies the perpetrators of such violence and equally condemns them regardless of their category - state and non-state actors - and the motivation behind such violence. This paragraph also provides for protection of activists working on issues of sexual orientation and gender identity, and calls on states to ensure an environment free from violence, attacks and reprisals against them.

The third and last paragraph is the executive part directing different stakeholders - primarily states as duty bearers - what to do to comply with their obligations towards sexual and gender minorities. These obligations include stopping violence and abuses, and creating an enabling environment free of stigma, reprisals or criminal prosecution for human rights defenders. For avoidance of any doubt, the Commission clarified that ending violence requires positive obligations on the part of the states, including enacting and effectively applying appropriate laws prohibiting and punishing all forms of violence including those targeting persons on the basis of their imputed or real sexual orientation or gender identities, ensuring proper investigation and diligent prosecution of perpetrators, and establishing judicial procedures responsive to the needs of victims.

These three positive obligations are related to legislative reforms and access to justice, including remedies for the victims. As such, it is argued that they are not subject to progressive realization but rather immediate enforcement given their nature of the rights they seek to protect and respect. Further in terms of Resolution 275, African States are arguably obligated to decriminalize same-sex relations and adopt protective laws that ensure that adults engaging in consenting same-sex relations or those with non-conforming gender identity live in full enjoyment of their rights, free from hatred, violence and discrimination. That is the minimum content of the phrase 'enacting and effectively applying appropriate laws prohibiting and punishing all forms of violence including those targeting persons on the basis of their imputed or real sexual orientation or gender identities' contained in the first part of Resolution 275(4).

Further, by virtue of Resolution 275(4) and given the plight of violence, impunity and the access to justice across Africa, states should consider creating LGBTIQA crime investigation units to ensure perpetrators are brought to book diligently and in a manner that is responsive to the needs of the victims. 
That is also the core meaning of the phrase 'ensuring proper investigation and diligent prosecution of perpetrators, and establishing judicial procedures responsive to the needs of victims' contained in the last part of Resolution $275(4) .{ }^{47}$

Despite the fact that the above steps are yet to be undertaken in any country across Africa, Resolution 275 has been used to educate and sensitize LGBTIQA community members, policy makers, other civil society organizations and the general public. In police trainings, before parliaments or technical groups such as law reform commissions, Resolution 275 has been used in ways that were not anticipated before. ${ }^{48}$

Two dialogues between African and the Inter-American human rights systems with UNAIDS and the United Nations mandate holders have resulted in reports that are used to educate various stakeholders ${ }^{49}$. These interventions serve to continuously identify ways of making progress in addressing the protection gaps faced by LGBTIQA with context-tailored approaches.

In March 2016, the first regional seminar to find practical solutions for ending violence and discrimination based on SOGIE in Africa was held in response to the call from Resolution $275 .{ }^{50} \mathrm{~A}$ final declaration clarifying different obligations and recommendations was adopted and published. ${ }^{51}$

Finally, the Commission has also been using Resolution 275 in states review and subsequent norms development work (general comments, guidelines and concluding observations).

\section{Conclusion}

The journey to Resolution 275 was long and the promises it brought to Africans is a manifestation of the virtues of Africa's historical traditions and the values of a civilization based on humanness 'Ubuntu', inclusiveness and respect for human dignity in our differences.

The adoption of Resolution 275 by the primary body in charge of protecting and promoting human rights in Africa is a culmination of tireless advocacy, educational and lobbying efforts. By adopting Resolution 275, the Commission simply did its overdue job. It sent a message that it does not exist to reflect the prejudices of member states, but to hold states accountable when they fail to observe the required human rights standards for all their citizens.

However, not all the Commission's work is rosy. The recent Decision 1015 of the African Union Executive Council ${ }^{52}$ and the response of the Commission - which withdrew CAL observer status in application of the above decision, without appreciating the impact of such move on its independence - are cause for concern. Further, given the contemporary criticism against human rights by left and right-wing regimes, ${ }^{53}$ the future of protection of sexual minority rights in Africa is uncertain and the likelihood of reversing the gains is high.

As a way forward, it is suggested to amplify advocacy around Resolution 275 given the lesser influence states have in the drafting and adopting resolutions. 
Further, it is urgent to get African states to speak out against the project of dismantling the accountability mechanisms that still exist on the continent. The African Charter is among the most ratified instruments and, therefore, enjoy a full commitment from states parties to realize the Charter's rights with the guidance of the Commission, including the authoritative interpretations formulated through resolutions, general comments, recommendations and decisions. It is only by doing so that Resolution 275 and other standards set by the Commission will deliver 'the Africa we want'.

\section{Notes}

1 V Balogun \& E Durojaye 'The African Commission on Human and Peoples' Rights and the promotion and protection of sexual and reproductive rights' (2011) 2 African Human Rights Law Journal 373.

2 In this chapter, the terms sexual and gender minorities are used as an umbrella expression to design persons who, due to their diverse sexual orientation (homosexuality) or gender identity (transgender), are referred to as LGBTIAQ+: lesbian, gay, bisexual, transgender, intersex, asexual, queer and others whose sexuality or gender identity is still under selfquestioning. Given the evolving and complex nature of human sexuality and gender self-identification, we acknowledge that all identities may not be exhaustively captured in the LGBTIAQ+ acronym. The expressions sexual orientation, gender identity or expression and sex characteristics (SOGIESC) are generically used to qualify a ground of discrimination or other human rights violations. In this chapter, these expressions are used interchangeably.

3 International Lesbian, Gay, Bisexual, Trans and Intersex Association, A Carroll \& L Mendos 'State sponsored homophobia 2017: A world survey of sexual orientation laws: Criminalisation, protection and recognition' (2017) 81106.

4 Such incidents have been documented and reported by AMSHeR and local African LGBTI organizations to the African Commission on Human and Peoples' Rights in an attempt to ensure steps are taken by the African Commission to protect the rights of sexual and gender minorities in Africa. These reports include reports on Cameroon, Senegal, Nigeria, Liberia, Malawi, South Africa, Namibia, Burundi, Sierra Leone, and Eritrea (on file with the author).

5 A Rudman 'The protection against discrimination based on sexual orientation under the African human rights system' (2015) 15 African Human Rights Law Journal 5.

6 A Shaw 'From disgust to dignity: Criminalisation of same-sex conduct as a dignity taking and the human rights pathways to achieve dignity restoration' (2018) 18 African Human Rights Law Journal 691-698.

7 K Kaoma 'The Vatican anti-gender theory and sexual politics: An African response' (2016) 6 Religion and gender 282, 292.

8 A study on health care provision to sexual and gender minorities in South Africa found that the lack of responsive mechanisms, combined with lack of training and knowledge about sexual and gender minority health ... and the complexity of healthcare providers' decision-making perpetuates the marginalization and invisibility of sexual and gender minority patients in health system. A Muller 'Health for all? Sexual orientation, gender identity and the implementation of the right to access health care in South Africa' (2016) 18 Health and Human Rights Journal 2014.

9 The Danish Institute for Human Rights, F Kerrigan 'Getting to rights: The rights of lesbians, gays, bisexuals, transgender, intersex persons in Africa' (2014) 123.

10 In discussing the limitations of the use of the right to privacy, Rudman argues that the use of the right to privacy to claim protection of sexual and gender minorities would 
leave the stigma completely untouched and the state would have no positive obligation towards homosexual persons. Rudman (n 6) 18.

11 For an account of violence based of one's sexuality, see report by AMSHeR \& CAL 'Violence based on perceived or real sexual orientation and gender identity' (2013) 11 44.

12 T Monica \& W Matthew 'Africa and the contestation of sexual and gender diversity: Imperial and contemporary regulations' in EB Michael et al (eds) The Oxford handbook of global LGBT and sexual diversity politics (2020) 207.

13 AMSHeR et al 'Alternative Report to the human rights situation of LGBT people in Cameroon' submitted for the review of the third periodic report of the Republic of Cameroon at the 54th ordinary session of the African Commission held in Banjul, The Gambia from 22 October to 5 November (on file with the author).

$14 \mathrm{~N}$ Poku et al 'Sustainable development and the struggle for LGBTI inclusion in Africa: Opportunities for accelerating change' (2017) 27 Development in Practice 2, 435.

15 As above 440.

16 UN OHCHR 'Born free and equal: Sexual orientation and gender identity in international human rights law' (2012) HR/PUB/12/06 8.

17 Balogun \& Durojaye (n 2) 373.

18 UN OHCHR (n 17).

19 Rudman (n 6) 11.

20 M Wayne 'Queering international human rights law' (2000) Sexuality in the legal arena 208-227 (Carl Stychin \& David Herman eds) in R Murray \& F Viljon 'Towards nondiscrimination on the basis of sexual orientation: Normative basis and procedural possibilities before the African Commission on Human and Peoples' Rights and the African Union' (2007) 29 Human Rights Quarterly 187.

21 UN OHCHR (n 17) 9.

22 R Garrido 'Patterns of discrimination based on sexual orientation in Africa: Is there a Lusophone exception?' (2019) 3 African Human Rights Yearbook 93-118 http://doi.org /10.29053/2523-1367/2019/v3a5? (accessed 21 April 2020).

23 G Mukundi \& A Ayinla 'Twenty years of elusive enforcement of the recommendations of the African Commission on Human and Peoples' Rights' (2006) 6 African Human Rights Law Journal 471, 478.

24 In the debate around the granting of observer status to CAL, the vice-chair referred to homosexuality as an 'imported virus to distract Africans from the real problems of poverty and corruption' https://www.youtube.com/watch?v=USc4anKo3-8 at 42:35 (accessed 14 January 2019). See also Rudman (n 6) 7, quoting the commissioner acting as rapporteur in the case of Curson v Zimbabwe (2000) AHRLR 335 (ACHPR 1995). The rapporteur in the case wrote: '[B]ecause of the deleterious nature of homosexuality, the Commission seizes the opportunity to make a pronouncement on it. Although homosexuality and lesbianism are gaining recognition in certain parts of the world, this is not the case in Africa. Homosexuality offends the African sense of dignity and morality and is inconsistent with positive African values'. E Ankumah The African Commission on Human and Peoples' Rights: Practice and procedures (1996) 174 in F Viljoen International human rights law in Africa (2012) 265. See also A Ibrahim 'LGBT rights in Africa and the discursive role of international human rights law' (2015) 15 African Human Rights Law Journal 273.

25 C Heyns 'A 'struggle approach' to human rights' in C Heyns \& K Stefiszyn (ed) Human rights, peace and justice in Africa: A reader (2006) 16.

26 S Tamale 'Exploring the contours of African sexualities: Religion, law and power' (2014) 14 African Human Rights Law Journal 175, 176.

27 H Hillgenberg 'A fresh look at soft law' (1999) 10 European Journal of International Law 499 in Balagon \& Durojaye (n 2) 379.

28 Murray \& Viljon (n 21) 100111.

29 Ibrahim (n 25) 272. 
30 Oxford online dictionaries https://en.oxforddictionaries.com/definition/strategy (accessed 14 January 2019).

31 United Nations, OHCHR 'Manual on human rights monitoring' (2011) 4.

32 See Alternative reports to states periodic reports submitted before the African Commission on Cameroon, Togo, Nigeria, Malawi, Namibia, Liberia, Sierra Leone, Burundi, etc. (on file with the Author). On positive narrative queer people in Africa, see AMSHeR 'Voices of Freedom' (2014) https://www.amsher.org/the-voices/ (accessed 21 December 2018).

33 Low compliance with the reporting obligations by states, uncertainty about the review schedule, etc. e.g. the review of the periodic report of Rwanda postponed at the 60th ordinary session after the 60th public session in Niamey had already started.

34 Temale (n 27) 170.

35 The NGO Forum is a three-day gathering organised ahead of each session to facilitate participation of non-governmental organizations with observer status to the session of the Commission.

36 This included invitation of Commissioners to intersession workshops on SOGI issues or using connections activists had with specific commissioners from their countries or based on common a history of working, studying or worshiping together.

37 For a full account of the responses of the Commission to SOGI resolutions submitted through the NGO Forum, see S Ndashe 'Seeking the protection of LGBTI rights at the African commission on human and peoples' rights' (2011) 15 Feminist Africa 19.

38 28th Activity report of the African Commission (2009), para 33 http://www.achpr.org/ files/activity-reports/28/achpr47eo8_actrep28_20092010_eng.pdf (accessed 14 January 2019).

39 Ndashe (n 38) 31.

40 No country accepted to come forward and host such a meeting and speculation have been ongoing that despite its legal framework and historical leadership on non-discrimination issues, South Africa did not want to take the lead as it would lose the support it needed from the Africa bloc to get a seat at the UN Human rights council. See e.g. E Jordaan 'South Africa and sexual orientation rights at the United Nations: Battling for both sides' (2017) 1-26 http://ink.library.smu.edu.sg/soss_research/2079 (accessed 21 December 2019).

41 Outcome document of the Oslo international conference on human rights, sexual orientation and gender identity (2013) https://outrightinternational.org/sites/default/files /Co-Chairs\%20Summary\%20of\%20Conclusions.pdf (accessed 21 December 2019).

42 The report was authored and presented by African organizations was deliberate and aimed at countering the argument of SOGIE issues being un-African.

43 The Special rapporteur on the situation of human rights defenders, Reine Alapini Gansou attended the NGO Forum and co-launched the report.

44 This inside information was received off the record from the Secretariat staff. This was confirmed by friendly commissioners during side interactions in subsequent sessions.

45 Owing to the cost of staying in Luanda - one of the most expensive cities in the world and the light programme of the session.

46 The then UN Secretary General, Ban Ki Moon and the High Commissioner for Human Rights expressed their congratulatory messages to the Commission for such a step in the right direction.

47 For a detailed description of action required to states and non-state actors arising from Resolution 275, see the booklet by AMSHeR \& Centre for Human Rights 'Resolution 275: What does it mean for states and non-state actors in Africa?' (2018) 1 http://www. chr.up.ac.za/images/researchunits/sogie/documents/resolution_275/resolution_275_ eng.pdf (accessed 14 January 2019).

48 See AMSHeR activity reports from resolution watch sessions (On file with the author). 
49 See the Report of the first joint dialogue https://www.ohchr.org/Documents/Issues/ Discrimination/Endingviolence_ACHPR_IACHR_UN_SOGI_dialogue_EN.pdf (accessed 21 December 2018).

50 Opening remarks by the Chair of the South African Human Rights Commission, Regional Seminar on finding practical solutions for ending violence and other human rights violations based on sexual orientation and gender identity or expression, held on 5th March 2016, in Ekurhuleni, South Africa.

51 Ekurhuleni Declaration (2016) https://www.oursplatform.org/wp-content/uploads/ EKURHULENI-DECLARATION-FINAL.pdf (accessed 21 December 2018).

52 Executive Council Decision at the 33rd ordinary session, 28-28 June 2018. EX.CL/1015(XXXIII) (2018).

53 M Langford 'Critiques of human rights' (2018) 14 Annual Review of Law and Social Science 83.

\section{References}

ACHPR (African Commission on Human and Peoples' Rights) Statement by the Special rapporteur on the situation of human rights defenders in Africa (2014) http://www .achpr.org/press/2014/03/d196/ (accessed 14 January 2019)

ACHPR (African Commission on Human and Peoples' Rights) Report of the first joint dialogue (2018) https://www.ohchr.org/Documents/Issues/Discrimination/Endingviolence_ ACHPR_IACHR_UN_SOGI_dialogue_EN.pdf (accessed 21 December 2018)

African Union, Executive Council Decision EX.CL (Dec. 1015 (XXXIII) https://au.int /sites/default/files/decisions/34635-ex_cl_dec_1008_-1030_xxxiii_e.pdf (accessed 14 January 2019)

AMSHeR 'Voices of freedom' (2014) https://www.amsher.org/the-voices/ (accessed 21 December 2018)

AMSHeR \& CAL 'Violence based on perceived or real sexual orientation and gender identity' (2013) 11

AMSHeR \& Centre for Human Rights 'Resolution 275: What does it mean for states and non-state actors in Africa?' (2018) http://www.chr.up.ac.za/images/researchunits/sogie /documents/resolution_275/resolution_275_eng.pdf (accessed 14 January 2019)

Ankumah, A 'The African Commission on Human and Peoples' Rights: Practice and procedures' (1996) 174 in Viljoen, F International human rights law in Africa (2012) 265

Balogun, V \& Durojaye, E 'The African Commission on Human and Peoples' Rights and the promotion and protection of sexual and reproductive rights' (2011) 2 African Human Rights Law Journal 373.

Garrido, R 'Patterns of discrimination based on sexual orientation in Africa: Is there a Lusophone exception?' (2019) 3 African Human Rights Yearbook 93.

Heyns, C (eds) 'A “struggle approach” to human rights' in C Heyns \& K Stefiszyn (eds) Human rights, peace and justice in Africa: A reader (Pretoria University Law Press 2006) 16. Hillgenberg, H 'A fresh look at soft law' (1999) 10 European Journal of International Law 499. Ibrahim, A 'LGBT rights in Africa and the discursive role of international human rights law' (2015) 15 African Human Rights Law Journal 273.

International Lesbian, Gay, Bisexual, Trans and Intersex Association, Carroll, A \& Mendos, LR 'State sponsored homophobia 2017: A world survey of sexual orientation laws: Criminalisation, protection and recognition' (2017) 81.

Jordaan, E 'South Africa and sexual orientation rights at the United Nations: Battling for both sides' (2017) 44 Politikon 1. 
Kaoma, K 'The Vatican anti-gender theory and sexual politics: An African response' (2016) 6 Religion and Gender 282.

Kerrigan, F Getting to rights: The rights of lesbians, gays, bisexuals, transgender, intersex persons in Africa (Danish Institute for Human Rights 2014).

Monica, T \& Matthew, W 'Africa and the contestation of sexual and gender diversity: Imperial and contemporary regulations' in Michael, E (eds) The Oxford handbook of global LGBT and sexual diversity politics (Oxford 2020)

Mukundi, G \& Ayinla, A 'Twenty years of elusive enforcement of the recommendations of the African Commission on human and peoples' rights' (2006) 6 African Human Rights Law Journal 471.

Muller, A 'Health for all? Sexual orientation, gender identity and the implementation of the right to access health care in South Africa' (2016) 18 Health and Human Rights Journal 2.

Ndashe, S 'Seeking the protection of LGBTI1 rights at the African Commission on Human and Peoples' Rights' (2011) 15 Feminist Africa 17.

Oxford Online Dictionaries https://en.oxforddictionaries.com/definition/strategy (accessed 14 January 2019)

Poku, N, Esom, K \& Armstrong, R 'Sustainable development and the struggle for LGBTI inclusion in Africa: Opportunities for accelerating change' (2017) 27(2) Development in Practice 2.

Rudman, A 'The protection against discrimination based on sexual orientation under the African human rights system' (2015) 15 African Human Rights Law Journal 5.

Shaw, A 'From disgust to dignity: Criminalisation of same-sex conduct as a dignity taking and the human rights pathways to achieve dignity restoration' (2018) 18 African Human Rights Law Journal 691.

Temale, S 'Exploring the contours of African sexualities: Religion, law and power' (2014) 14 African Human Rights Law Journal 175.

United Nations, OHCHR Born free and equal: Sexual orientation and gender identity in international human rights law (OCHR 2012).

United Nations, OHCHR Manual on human rights monitoring (United Nations 2011).

Wayne, M 'Queering international human rights law' (2000) Sexuality in the Legal Arena 208-227 (Carl Stychin \& David Herman (eds) in R Murray \& F Viljon 'Towards non-discrimination on the basis of sexual orientation: Normative basis and procedural possibilities before the African Commission on Human and Peoples' Rights and the African Union' (2007) 29(1) Human Rights Quarterly 87. 